\title{
EXPLORING THE RELATIONSHIP BETWEEN SMART CITY, SUSTAINABLE DEVELOPMENT AND INNOVATION AS A MODEL FOR URBAN ECONOMIC GROWTH
}

\author{
Procopie Florin Gușul ${ }^{1}$, Alina Ramona Butnariu ${ }^{2}$ \\ 1 "Ștefan cel Mare" University, Faculty of Economic Sciences and Public Administration, \\ Suceava, Romania \\ 2"Ștefan cel Mare" University, Faculty of Economic Sciences and Public Administration, \\ Suceava, Romania \\ gusulprocopieflorin@gmail.com \\ alinaramonabutnariu@gmail.com
}

\begin{abstract}
In this paper we focus on the concept of smart city, defined as cities where investments in human and social capital and infrastructure, along with ICT progress and innovation fuel the sustainable economy and stimulate growth in quality of life, with a focus on smart natural resource management. We envision smart city as a concept that highlights important aspects of sustainability, such as the need for responsible resource management, energy efficiency and citizen involvement. Given the current understanding of the smart city concept, it is unclear whether it has the necessary features to ensure sustainability. We believe that this aspect is due to the fact that smart cities are extremely complex and interdependent. Their study and analysis would therefore require an inter- and transdisciplinary approach that allows an adequate overview of this concept, to the convergence of several areas, such as urban development, technology, economics, engineering and social sciences, etc. We believe that this research will contribute to the already existing theories of smart cities and will help maximize the potential for this smart city concept to be a viable solution for sustainable development in our increasingly urbanized world, especially as the latest statistics confirm an upward trend in EU-level indicators on sustainable cities and communities. Moreover, the theory of smart growth is being discussed, but not as an antagonist alternative, but rather as an addition integrative to the concept of sustainable development of smart cities. In our opinion, smart city solutions would not be efficiently implemented and helpful to communities in absence of a vision for the smart and sustainable future.
\end{abstract}

Keywords: smart city, sustainable development, innovation, urban growth.

JEL Classification: 031, Q01.

\section{Introduction}

Cities have nowadays a key role in solving a wide variety of issues and needs of citizens and organizations given the fast-growing urbanization and current sustainability challenges. This is why public administrations and other stakeholders need to tackle urban dilemmas and develop new governance models in order to address these challenges in an effective and efficient manner. It is relatively recently that a novel concept relevant to the sustainable development of urban areas, namely smart city, has emerged, and this concept takes into account the benefits of applying information and communication technologies (ICT) in fields of development such as environmental protection, local economy, education or even social inclusion. social. Experts and practitioners in the field, such as designers or engineers believe that through widespread use of ICT, it might become possible for a system to become more efficient and effective in the use of its available resources, by encouraging economic competitiveness and tackling the long-debated issues of cities, such as poverty 
or social exclusion. However, we have seen along the past decades that this concept is still lacking in conceptual clarity; nevertheless, it is widely applied in practice. We concur to the general opinion that there is small understanding as to the real contribution of the concept of smart city to sustainability issues in what concerns urban development.

Debating on the impact of smart city on sustainable development is thus not an easy task since they are both complex phenomena driven by a variety of factors that support the (re)modeling of contemporary cities. We can easily observe that they are not just fashionable words, concepts or labels associated with urban marketing as they are really implemented in a grounded way, successfully or not across the world, in order to solve the problems of cities on a global level. The biggest challenge of a fast urbanization is undoubtedly the future of cities. Therefore, the implications of urban development in cities and weather it is sustainable or not, is essentially important at both micro and macro level, that is to individuals and to the whole planet. It is only natural to think of sustainability in times like this as any development consumes resources. While the impact of climate change becomes increasingly visible, there is an increasing need to urgently shift to a low-carbon model. In addition to this, as globalization and market forces continue to inevitably create extreme changes in society, there is an even greater need to identify and implement innovative solutions which will transform both societies and economies to become more inclusive and liveable to citizens.

When considering the sustainable smart city, we identify many strong global trends that have the potential to be addressed, such as climate change, social inequality or poverty. There is an increasing interest in sustainability, in the transformative power of urbanization and all opportunities that technological and digital innovation could offer and all these might be capitalized in achieving the goals of urban growth, alongside with others that have been universally recognized through the UN Sustainable Development Goals.

In an urban area, digital innovations are meant to reshape every sector, such as energy, where technologies such as smart grids can optimize the integration of renewable energy into e-government applications that make municipal governments more open, transparent and accountable. Another sector of great interest is mobility since cities are getting more crowded every day and pressure on the old-fashioned infrastructure is getting citizens to revolt on political factors. Innovations to help tackle traffic jams and support eco-friendly ways of transportations are implemented more and more often with a real potential to gaining more popularity as fuels are scarce around the globe. Perhaps one of the strongest trends is smart governance who uses new forms of communication with stakeholders and data accessibility to mobilize the necessary networks and resources around solving local urban problems. However, although it often seems that the power of technology is transformative or innovative, a long-term strategy, a concrete action plan and a clear vision are more suitable for the development of a society than implementing quick solutions which work for only a short limited period of time. This aspect has been exemplified in the case of several cities around the world, which have managed to implement smart or green solutions to reinvent themselves, to create an image of themselves as being attractive, competitive and eco-friendly by creating world-renowned developments. Still, in many of these cases, this does not mean that they have eradicated or solved all socio-economic problems. On the contrary, these municipalities didn't stop fighting to address these issues while developing high-performance innovative solutions. This proves that rigidity in some respects intertwines with a certain dynamic of development and urban growth. In particular, we found that a special inertia is surrounding the power structures as urban infrastructure can last for decades, creating problems when investments are lacking. Therefore, strong action is required from by policymakers to address these problems because the changes promised by the sustainable smart city in the future are more likely to occur with support from innovation that acts subtly and incrementally, and not suddenly and radically. However, we consider that as long as cities move along a path that creates more prosperous and 
equitable societies, all within ecological limits, then this slow movements is enough to consider it progress towards urban growth.

\section{Smart city as socio-technical imaginary}

Cities are dynamic and complex constructs at the centre of the challenges posed by continuous development and sustainability (Radecki, 2018; Caragliu, Bo and Nijkamp, 2009). With increasing economic productivity, the world today faces major societal challenges, such as scarcity of resources, environmental pollution, traffic congestion, climate change, population aging and migration, human health problems, sometimes even extreme and globally spread social and economic challenges such as the COVID-19 pandemic. As economic productivity increases in cities, urbanization seems to be the most likely cause of some of these challenges (Palgan, Evans, \& Schliwa, 2015). Cities are recognized as the main agents of change when it comes to addressing these challenges, even if they extend to regions, nations and even continents (Schuurman et al., 2012). The need for cities to respond to these challenges has led them to find smarter and more innovative ways to solve these problems (Chourabi et al., 2012). Therefore, cities are increasingly described in connection with the notion of smart city or innovation. But where does this trend come from?

People have always used their imagination to project what the future might look like and try to make it happen. These sometimes idealistic and highly creative visions of future societies, however, have been throughout history a little too advanced to follow or implement due to lack of knowledge, technology, tools, or insufficient capacity. Today, however, imaginaries or visions of the future are no longer restricted to science fiction or utopian constructs, but represent, as Jasanoff and Kim (2009) argue, an important resource that allows for new forms of imagining life by designing optimistic and at the same time achievable goals. Visions are in this case no longer the product of individuals projecting their future, but are shared and contextualized into wider, often political frameworks. This kind of imaginaries allow collective interpretations of social reality (Castoriadis, 1987) and can form a solid basis for that feeling of belonging to a community, attaching to it organically. A step further is taken by Jasanoff \& Kim (2009) when they emphasize that the imagination can be seen as an organized field of social practices, which serves a key component in creating social order.They introduce the concept of "socio-technical imaginary" as a tool that proved the power of imagining the possible future and what an important aspect of social life as a whole that is. Also, the socio-technical imaginary shows the way in which the collective visions about the desired and feasible technical-scientific futures are described (Ballo, 2015).

We have no doubt that socio-technical imaginaries are able to sustain the need for political decisions or have the capacity to justify new investments in science and technology, can encourage types of technological processes or, in fact, justify the inclusion or exclusion of different social actors, ideas that are particularly important for the development of smart cities (Jasanoff, 2015). This is because cities that implement smart solutions include networks of people, organizations, institutions, and companies that position themselves in a certain way to achieve their goals for the future. In the case of smart cities, we can see that they often are presented as a solution, as a real vision and an imaginary already achieved regarding the future cities, what solutions they implement, how and for whom they are organized. It is important to remember that such imaginaries are not neutral constructs, because they are organized in ways in which some elements are included and some, on the contrary, excluded or less visible in the attention of decision makers. From this perspective, there are smart cities with strong social components, others that put more emphasis on technology or administration. Equally, depending on the various needs and urban emergencies, smart and innovative solutions will emerge into projects implemented 
in various fields: mobility, energy, human resources, education, etc. In this context, smart cities appear as one of the solutions and trends to mitigate and solve global and local problems (Castelnovo, 2018).

In our opinion, smart city is a socio-technical imaginary due to the fact that everywhere in the world, across Europe and especially in the European Union, it is embedded in political and innovative strategies for the future. Smart city is promoted mainly through the way in which new smart technologies manage to make urban spaces more efficient, use resources better, reduce greenhouse gas emissions, manage energy production and become more sustainable. In other words, the smart city model has been enthusiastically embraced by stakeholders and decision makers around the world, promising everything from advanced technology to high living standards for citizens. Without innovations and technological progress not only that this idealistic construct of the future would not be possible, but it will also not be sustainable.

\section{Sustainable urban development policies in a smart innovative context}

Recent studies and policies highlight the synergies and benefits of connecting the principles of sustainable and smart urban development. We find it relevant that the most cited report of the World Urbanization Prospects series at United Nations not only documents a consistent trend of global urbanization in the past, but also clearly postulates that this trend will continue to rise at least until 2050. More importantly in our opinion, it calls for integrated policies to improve urban and rural living conditions and emphasizes the role of technology and innovation in mitigating sustainability challenges. As stated in this report, the political implications resulting from this study include, inter alia, the need to have accurate, consistent and timely data. These are needed for policy development, as well as the efficient use of ICT to facilitate a sustainable way of urbanization, one that improves and streamlines the provision of services to urban stakeholders. The United Nations has already begun to direct its research in this direction, by exploring the role of Big Data for sustainable development (United Nations, 2015).

European Union policies also highlight the synergy between smart technologies and sustainable urban development. With the emergence of the Europe 2020 Strategy, the goals of promoting smart, inclusive and sustainable growth in Europe have been set. The strategy is based on innovation, which is seen as a means of addressing challenges, including climate change and energy efficiency. Furthermore, through the European Innovation Partnership for Smart Cities and Communities, launched by the European Commission in 2012, the energy, transport and ICT industries are invited to cooperate with cities to meet their development needs. This will allow innovative, integrated and efficient technologies to launch and enter the market more easily, turning cities into poles of innovation (European Commission, 2012). The relationship between the concept of smart city and that of sustainable development is also reflected in the EU's regional and urban development policy, which sees green technology as an asset for reducing greenhouse gas emissions and encouraging the intelligence and innovation of urban communities (European Commission, 2011).

The central role of cities in sustainable development is clearly reflected in the Sustainable Development Goals (SDGs) of the United Nations 2030 Agenda for Sustainable Development (2015), namely to make cities and human settlements inclusive, safe, resilient and sustainable. We find that the defining role of cities in sustainable development globally and locally is now well documented (European Commission, 2011; United Nations, 2015). That being said, since the early years of the popularization of the smart city concept, a considerable number of its definitions have included the goal of sustainability (Caragliu et al., 2011; Giffinger, Fertner and Meijers, 2007; Schaffers et al., 2011) and refer to terms 
such as "smart environment", "smart energy", "smart utilities", "smart water management systems" and other concepts related to the environment as an integral part of the smart city (Giffinger, Fertner and Meijers, 2007; Telecommunications International, 2014; Komninos, 2011; Lombardi, Giordano and Farouh, 2012; Zubizarreta et al., 2013). This broad category of "smart environment" refers in fact to the ability of smart city tools and applications to improve the environment by introducing ecological technologies, allowing for better and more accurate monitoring of how urban resources are consumed. Marsal-Llacuna et al. (2015) actually identify the origins of smart cities in ecological and habitable cities. They explain that the smart city embodies the principles of sustainable development alongside with the quality of life, which in turn are enhanced by modern and advanced ICT. The inclusion of "sustainability" in the concept of smart city has also been confirmed by other research as well in the form of reviews of smart city domains.

Moreover, in a review of 61 applications from a total number of 33 smart cities, Zubizarreta et al. (2013) found that applications related to environment occupy $18.03 \%$ of the total, thus revealing the fact that environment is an integral part of the smart city. Also, Albino, Berardi and Dangelico (2015) confirm that issues related to the environment, energy and sustainability in cities are included in many definitions of the smart city.

At the same time, the smart city concept emerges from the efforts of a multitude of stakeholders in generating opportunities and providing not only a bright future such as socio-technological imaginaries, but also adequate basic facilities, such as drinking water supply, sewerage and living conditions, and the provision of satisfactory minimum basic infrastructure, with better environmental conditions and a better quality of life, with the support of health and socio-cultural infrastructure ensuring the mobility of people, goods and services. Obviously, cities, compared to rural localities, are preferable and better places for a more qualitative way of living, with innovative and modern tools suitable for experimenting and working. The concept of "smart" reflects, in our opinion, the perception of such expectations and aspirations from citizens. Equally, smart city is able to ensure efficient management of available natural resources through participatory actions involving citizen elections and public-private partnership programs. To achieve an increase in the quality of life, we mention some important features of the smart city concept:

- Respect for the environment and energy;

- Use of digital information and communication technology;

- Sustainable development of different sectors of the economy.

Taking into consideration the above, smart city is nothing more than an approach to sustainable development that responds technologically to resource conservation and natural climate change. The city is designed to achieve the 17 goals and all targets of the United Nations Sustainable Agenda from September 2015 faster and more efficiently. The interplay of smart and sustainable development goals is illustrated in Table 1.

Table 1: Convergence of the UN Sustainable Development Agenda 2015 and the components of Smart City

\begin{tabular}{|c|c|c|}
\hline $\begin{array}{c}\text { Goal } \\
\text { no. }\end{array}$ & UN Agenda for sustainable development & Smart city component \\
\hline 1 & $\begin{array}{l}\text { No poverty - Eradicating poverty in all its forms and } \\
\text { in any context }\end{array}$ & Smart environment \\
\hline 2 & $\begin{array}{l}\text { "Zero" hunger - Eradicating hunger, ensuring food } \\
\text { security, improving nutrition and promoting } \\
\text { sustainable agriculture }\end{array}$ & $\begin{array}{l}\text { Smart economy } \\
\text { Smart governance }\end{array}$ \\
\hline 3 & $\begin{array}{l}\text { Health and well-being - Ensuring a healthy life and } \\
\text { promoting the well-being of all at any age }\end{array}$ & $\begin{array}{c}\text { Smart living } \\
\text { Smart governance }\end{array}$ \\
\hline 4 & $\begin{array}{l}\text { Quality education - Ensuring quality education and } \\
\text { promoting lifelong learning opportunities for all }\end{array}$ & $\begin{array}{c}\text { Smart living } \\
\text { Smart governance }\end{array}$ \\
\hline
\end{tabular}




\begin{tabular}{|c|c|c|}
\hline $\begin{array}{l}\text { Goal } \\
\text { no. }\end{array}$ & UN Agenda for sustainable development & Smart city component \\
\hline 5 & $\begin{array}{c}\text { Gender equality - Achieving gender equality and } \\
\text { empowering all women and girls }\end{array}$ & $\begin{array}{c}\text { Smart living } \\
\text { Smart governance }\end{array}$ \\
\hline 6 & $\begin{array}{c}\text { Clean water and sanitation - Ensuring the availability } \\
\text { and sustainable management of water and } \\
\text { sanitation for all }\end{array}$ & Smart environment \\
\hline 7 & $\begin{array}{c}\text { Clean and affordable energy - Ensuring everyone's } \\
\text { access to affordable energy in a safe, sustainable } \\
\text { and modern way }\end{array}$ & Smart environment \\
\hline 8 & $\begin{array}{l}\text { Decent work and growth - Promoting sustained, } \\
\text { open and sustainable economic growth, full and } \\
\text { productive employment and decent work for all }\end{array}$ & Smart economy \\
\hline 9 & $\begin{array}{l}\text { Industry, innovation and infrastructure - Building } \\
\text { resilient infrastructure, promoting sustainable } \\
\text { industrialization and encouraging innovation }\end{array}$ & Smart economy \\
\hline 10 & $\begin{array}{l}\text { Reduced inequalities - Reducing inequalities within } \\
\text { and across countries }\end{array}$ & Smart living \\
\hline 11 & $\begin{array}{l}\text { Sustainable cities and communities - Develop cities } \\
\text { and human settlements so that they are open to all, } \\
\text { safe, resilient and sustainable }\end{array}$ & $\begin{array}{l}\text { Smart living } \\
\text { Smart governance }\end{array}$ \\
\hline 12 & $\begin{array}{l}\text { Responsible consumption and production - Ensuring } \\
\text { sustainable consumption and production patterns }\end{array}$ & $\begin{array}{l}\text { Smart economy } \\
\text { Smart living } \\
\text { Smart governance }\end{array}$ \\
\hline 13 & $\begin{array}{c}\text { Climate action - Take urgent action to combat } \\
\text { climate change and its impact }\end{array}$ & $\begin{array}{l}\text { Smart environment } \\
\text { Smart governance }\end{array}$ \\
\hline 14 & $\begin{array}{c}\text { Aquatic life - Conservation and sustainable use of } \\
\text { oceans, seas and marine resources for sustainable } \\
\text { development }\end{array}$ & Smart environment \\
\hline 15 & $\begin{array}{c}\text { Terrestrial life - Protecting, restoring and promoting } \\
\text { the sustainable use of terrestrial ecosystems, } \\
\text { sustainable forest management, combating } \\
\text { desertification, halting and repairing soil degradation } \\
\text { and halting biodiversity loss } \\
\end{array}$ & Smart environment \\
\hline 16 & $\begin{array}{c}\text { Peace, justice and efficient institutions - Promoting } \\
\text { peaceful and inclusive societies for sustainable } \\
\text { development, access to justice for all and the } \\
\text { creation of efficient, responsible and inclusive } \\
\text { institutions at all levels }\end{array}$ & $\begin{array}{l}\text { Smart living } \\
\text { Smart governance }\end{array}$ \\
\hline 17 & $\begin{array}{l}\text { Partnerships to achieve the objectives - Strengthen } \\
\text { the means of implementation and revitalize the } \\
\text { global partnership for sustainable development }\end{array}$ & $\begin{array}{l}\text { Smart governance } \\
\text { Smart economy }\end{array}$ \\
\hline
\end{tabular}

Source: own elaboration of the authors.

However, the presence of the environmental dimension is quite abstract in the literature on smart cities, with specific subdomains, objectives, measures and performance values largely still remained under question (Komninos, 2016). This is a very specific challenge for orienting smart cities towards sustainability goals, given that smart cities are more of a strategy than a reality, a strategic vision for the future and, as such, smart cities should be systematically and holistically addressed (Schaffers et al., 2011; Nam and Pardo, 2011). Smart city is an idea of where the city wants to be in the future and how it imagines itself transformed, taking advantage of the capabilities of digital technology and innovation networks. In most cases, it is not something that can be achieved here and now, but at best it is a strategic approach to meeting long-term development aspirations. To become a smart city, a set of requirements applies: a comprehensive sequence of strategic choices, a high 
commitment of resources, monetary investment and the involvement of stakeholders with sometimes overlapping or conflicting roles. All this needs to be coordinated and managed in accordance with a clearly defined policy framework.

In our opinion, the knowledge economy alongside with innovation are the most essential drivers that influence the appearance and development of the smart city concept. The technological progress that has strived over the last decades have had an immense impact on cities and rooted their development in knowledge and innovation (Komninos, 2011). On the whole, the knowledge-based economy played a vital role in the emergence of smart cities discourse and shaped the principles that rule the concept. Still, without a clear vision of the future, with no thought on the sustainability of "smart", with no policies in this direction, there would be no smart city in the future to debate on.

\section{Sustainable development versus smart urban growth}

Without bringing prejudice to the rather simple definition of the concept of sustainable development, there seems to be among experts worldwide an on-going debate as to how the concept should be put into practice. We have no doubts about its growing popularity; however the implementation is not clear-cut obvious (Berke et al., 2007).

By definition, urban planning is being considered sustainable if the built environment becomes liveable, thus ecosystems being improved and protected; economic development is becoming more sensitive to local needs, in opposition to the gains of the elite, and it becomes more evident to observe the benefits of improving economic and environmental conditions. In 2003 it was stated that a community is sustainable when the neighborhood became the foundation of urban design and was characterized by mixed-use development, walking facilities and mixed-income housing. There were attempts to integrate sustainable development into urban planning and this endeavour has been largely linked to the concept of smart growth or development. While the relationship between the two concepts remains debatable, some writers argue that smart development is similar to sustainable development (Porter, 2002).

Smart growth has become lately an important concept in discourses on public policy and is known to provide some answers to the long-standing problems of development and its many detrimental consequences. It represents a paradigm shift and a broad rethinking of the consequences of uncontrolled urban growth (Burchell, Listokin, \& Galley, 2000; Janssenjansen, 2005; Edwards and Haines, 2007). Published in the 1990s, the concept offers a compelling insight into how to revitalize and ensure the competitiveness of urban areas from an economic point of view and to improve the quality of the environment. In most urban areas around the world, the conventional model of low-density development has succeeded in causing problems with transportation systems, degradation of the environment and has lead ultimately to the loss of agricultural land, natural areas and other urban open spaces. This situation has required innovative rethinking and action around the world and has generally been termed as "smart growth" (Katz, 2002).

Such development is built on a set of principles that provide guidance in order for communities and neighbourhoods to join efforts to promote development activities that ensure an improved quality of life, environmental conservation, economic revitalization and, most importantly, a sense of community. Smart growth discourages potential urban development models that operate independently of the vision of communities and results in development solutions that are inconsistent or incompatible. Smart Growth America defines this concept as one that builds urban, suburban, and rural communities with options that are available. We find that this definition promotes above all local economies, but also the creation of safe and beautiful communities with easy access to all. 
We find that the principles of smart growth consist of sufficiently generous themes. In the long-cited publication, "Getting to Smart Growth", the Smart Growth Network highlights ten principles of smart growth, which include:

- development with mixed uses;

- compact development / building design;

- range of housing options and opportunities;

- creating neighbourhoods where citizens can walk;

- promoting unique and attractive communities with a strong sense of belonging;

- conservation of agricultural lands, open spaces, natural beauty and the environment;

- intensifying and orienting development towards existing communities;

- providing a variety of transportation options;

- making predictable, cost-effective and correct development decisions;

- encouraging the participation of the community and stakeholders in development decisions.

The smart growth movement has been a source of controversy in public discussions and debates on urban planning worldwide. There are some arguments in favour of smart growth that have often focused on infrastructure and cost savings on public services, transport savings, economic development and environmental protection and conservation. We believe that the construction of compact neighbourhoods and communities express the lower need for additional public spending on the provision of services and infrastructure beyond urban or community boundaries. In this kind of communities, smart solutions that envision sustainable development are highly required and implemented. At the same time, conventional communities with single-use, low-density development models were considered financially burdened by the costs of maintaining and replacing of the existing infrastructure. On the contrary, a higher density within cities and communities leads to a more efficient use of land and requires a smaller area allocated to roads and utilities. Similarly, density makes it easier for communities and neighbourhoods to access alternative travel options, such as public transportation, cycling, and walking. Litman (2014) states an impressive fact: it seems that residents of smart-growing communities own between 10 and 30 percent fewer vehicles and drive 20 to 40 percent less mileage annually than in selfreliant communities. Implementing smart growth policies reduces car dependency and helps urban dwellers avoid the high cost of fuel, insurance and parking fees.

In addition, smart growth enables the development of the local economy by increasing productivity, property values, tax revenues and business activity. Due to their obvious benefits and savings which result from the efficient provision of public services and improved infrastructure, congestion and accessibility that reduce transport costs and reduce per capita consumption, these policies are encouraged to be implemented alongside with smart city solutions in order to enhance the attractivity from a numerous points of view of communities. We conclude by stating that this concept of smart urban growth does not antagonize the concept of sustainable development, but rather it completes it and provides useful information on the strategies that should be adopted to improve the social, economic and environmental effectiveness of smart cities development in relationship with innovation and future progress of society.

\section{In conclusion}

In this paper we have shown that sustainable development is a clear goal of the smart city because, as the visions and promises of the future are not simple, similarly, the smart city solutions are complex, integrated and dynamic. The concept of "sustainable smart city" is an important one since progress of ICT and technology could help alleviate the problems 
of increased urbanization or sustainable development. We conclude by saying that, although ICTs have a clear potential to solve sustainability problems in cities, there are sufficient reasons for interested urban stakeholders to be careful not to create a sandcastle, even more fragile than before.

\section{Acknowledgement}

This work is supported by project POCU 125040, entitled "Development of the tertiary university education to support the economic growth - PROGRESSIO", co-financed by the European Social Fund under the Human Capital Operational Program 2014-2020.

\section{References}

1. Albino, V., Berardi, U. și Dangelico, R. M. (2015) „Smart Cities: Definitions, Dimensions , Performance, and Initiatives”, (February). doi: 10.1080/10630732.2014.942092.

2. Ballo, I. F. (2015) „Imagining energy futures : Sociotechnical imaginaries of the future Smart Grid in Norway", Energy Research \& Social Science. Elsevier Ltd, 9, pp. 9-20. doi: 10.1016/j.erss.2015.08.015.

3. Berke, P. R. et al. (2007) „Are We Planning for Sustainable Development ?”, (June 2013), pp. 37 41.

4. Burchell, R. W., Listokin, D. și Galley, C. C. (2000) „Smart Growth : More Than a Ghost of Urban Policy Past , Less Than a Bold New Horizon", 11(4), pp. 821-879.

5. Caragliu, A. et al. (2011) „Smart Cities in Europe Smart Cities in Europe”, (October 2012), pp. 37 41. doi: 10.1080/10630732.2011.601117.

6. Caragliu, A., Bo, C. Del și Nijkamp, P. (2009) „Smart Cities in Europe Smart cities in Europe Introduction What is the source of urban growth and of sustainable urban development? This question has received", (May 2014). doi: 10.1080/10630732.2011.601117.

7. Castelnovo, W. (2018) „Co-production Makes Cities Smarter : Citizens ' Participation in Smart City Initiatives", (February). doi: 10.1007/978-3-319-30558-5.

8. Castoriadis, C. (1987). The imaginary institution of society. Cambridge: MIT Press.

9. Chourabi, H. et al. (2012) „Understanding Smart Cities : An Integrative Framework Understanding Smart Cities : An Integrative Framework", (July 2014). doi: 10.1109/HICSS.2012.615.

10. Edwards, M. M. and Haines, A. (2007) „Evaluating Smart Growth”, (September 2014). doi: 10.1177/0739456X07305792.

11. European Commission (2011), Cities of Tomorrow. Challenges, Visions, Ways Forward, Publications Office of the European Union, Brussels.

12. European Commission (2012), Communication from the Commision: Smart Cities and Communities - European Innovation Partnership, European Commission, Brussels.

13. Giffinger, R., Fertner, C. și Meijers, E. (2007) „City-ranking of European medium-sized cities Cityranking of European Medium-Sized Cities", (January).

14. Janssen-jansen, L. B. (2005) „Beyond Sprawl: Principles for Achieving More Qualitative Spatial Development", pp. 36-41.

15. Jasanoff, S. (2015) „Future Imperfect: Science, Technology, and the Imaginations of Modernity”, pp. 1-49.

16. Jasanoff, S. and Kim, S.-H. (2009) „Containing the Atom : Sociotechnical Imaginaries and Nuclear Power in the United States and South Korea", pp. 119-146. doi: 10.1007/s11024-009-9124-4.

17. Katz, B. (2002) „Smart Growth : The Future of the American Metropolis ?”.

18. Komninos, N. (2016) „Intelligent cities : Variable geometries of spatial intelligence Intelligent cities : Variable geometries of spatial intelligence", 3(July 2011). doi: 10.1080/17508975.2011.579339.

19. Litman, T. (2014) „Evaluating Criticism of Smart Growth”.

20. Marsal-llacuna, M., Colomer-llinàs, J. și Meléndez-frigola, J. (2015) „Technological Forecasting \& Social Change Lessons in urban monitoring taken from sustainable and livable cities to better address the Smart Cities initiative", Technological Forecasting \& Social Change. Elsevier Inc., 90, pp. 611-622. doi: 10.1016/j.techfore.2014.01.012. 
21. Nam, T. and Pardo, T. A. (2011) "Conceptualizing Smart City with Dimensions of Technology , People, and Institutions", (February 2014). doi: 10.1145/2037556.2037602.

22. Palgan, Y. V., Evans, J. și Schliwa, G. (2015) „Urban Living Labs for Sustainability and Low Carbon Cities in Europe: Towards a Research Agenda", (January 2016). doi: 10.1016/j.jclepro.2015.08.053.

23. Porter, D. Making Smart Growth Work; Urban Land Institute: Washington, DC, USA, 2002.

24. Radecki, A. von (2018) Innovation Ecosystems for Smart Cities A thematic Report.

25. Schaffers, H. et al. (2011) „Smart Cities and the Future Internet: Towards Cooperation Frameworks for Open Innovation Smart Cities and the Future Internet: Towards Cooperation Frameworks for Open Innovation The concept of " smart cities " has attracted considerable attention in the context of", (June 2014). doi: 10.1007/978-3-642-20898-0.

26. Schuurman, D. et al. (2012) „Smart Ideas for Smart Cities: Investigating Crowdsourcing for Generating and Selecting Ideas for ICT Innovation in a City Context", 7(3), pp. 49-62. doi: $10.4067 /$ S0718-18762012000300006.

27. United Nations (2015), Transforming Our World: The 2030 Agenda for Sustainable Development, New York, NY, available at: https://sustainabledevelopment.un.org/post2015/transformingourworld).

28. Zubizarreta, I. et al. (2013) „Smart City Concept: What It Is and What It Should Be”, pp. 1-8. doi: 10.1061/(ASCE)UP. 